\title{
Tissue Engineering Applications in Maxillofacial Surgery
}

\author{
Seied Omid Keyhan, Hamidreza Fallahi, \\ Alireza Jahangirnia, \\ Seyed Mohammad Reza Masoumi, \\ Mohammad Hossein Khosravi and \\ Mohammad Hosein Amirzade-Iranaq \\ Additional information is available at the end of the chapter
}

http://dx.doi.org/10.5772/intechopen.70904

\begin{abstract}
Nowadays, oral and maxillofacial surgeons face serious difficulties in reconstruction of large defects caused by trauma, cancer, or congenital deformities. Considering each part of oral and maxillofacial region consisting of several tissues, it is necessary to reconstruct these architectures layer by layer. Through years surgeons use different forms of grafts to reconstruct these defects. As these grafts and techniques are well described and used routinely, it should have been noticed that they are not without complications. This is where idea behind tissue engineering steps in. "Tissue engineering" due to its multi-aspect properties can be defined as application of methods and science of engineering toward the understanding of structure-function relationships of mammalian tissues in both normal and pathological forms to improve and develop biologic substitutes to reach the main goal of restoring, maintaining, and stabilization of tissue function. From standpoint of surgery, tissue engineering is not considered as a potential step anymore, but as an available approach to reach the ultimate goal of reconstruction procedures. The aim of this chapter is to defne concepts and advances in tissue engineering (TE). Also, review TE applications in the field of oral and maxillofacial surgery with bolding its clinical applications and complications based on novel and high-quality published researches.
\end{abstract}

Keywords: tissue engineering, scaffolds, bioprinting, stem cells, regenerative medicine, oral surgery, maxillofacial surgery 


\section{Introduction}

For the first time, Langer and Vacanti introduced the definition of tissue engineering [1] to explain the basics of functional substitutes for tissue damage and how to reconstruct and regenerate these tissues based on principles of biology and medical engineering. This new field in contrast to the former biomaterial thoughts presents incredible disciplines which diverse the goal of regeneration induction of traumatized or damaged tissue rather than substitution with inert parts. In recent decades, a number of articles were being published about the tissue engineering and regenerative medicine (TERM) field over 360 yearly just at the beginning of the twenty-first century. Just in 2010, the number of original articles in this field reaches 4000 . This over-increasing attraction to this field-involving almost all tissues even whole organs-leads to researches across the world [2].

Herein, we review latest scientific researches and recent advances of tissue engineering in major field of oral and maxillofacial surgery by subtopics categorized by facial complex parts.

\section{Basic principles of tissue engineering}

Tissue engineering is composed of three pillars: the cells, scaffolds, and growth factors. The combination of cells in a suitable scaffold was designed by the appropriate biochemical signals that can facilitate and make possible growth, so it could be a treatment option that is very suitable for clinical application. Various studies have shown that one of the important issues is proper design of scaffolds and associated mechanical signals to regulate tissue that is engineered. Scaffold that can be temporarily or permanently used for three-dimensional porous can also be natural or artificial, which in any case must be biocompatible [3]. A biocompatible environmental issue is crucial importance because it facilitates progenitor cells for migration and differentiation [4]. Some of the important issues that include the physical properties of the scaffold such as biodegradability, porosity, hardness and strength to be as much in excess of migration, cell adhesion, and proliferation (such as osteoconduction), which reflects the influence of signals on the cell is followed by the clinical efficacy of chemical signals and ultimately success factor for the link to be followed. Perhaps the problem for surgeons and maxillofacial surgery is more important than other counterparts, being careful scaffold designing on human anatomy for the repair of any defects in the face. Various studies designed to use the computer in the exact scaffold have shown promising results and have built a biomimetic scaffold that has special significance [5].

To complement these three pillars, tissue, cell lines that require ease of access and availability, differentiation capacity, and lack of stimulation of the immune system or have tumor genesis [6]. Choosing the right cell lines in tissue engineering is still under discussion. New research hopes to use stem cells and gene therapy with viral vectors to express growth factors in cultured cell lines successfully, but stem cell research is outside the scope of this topic [7]. Today, the laboratory of tissue engineering that leads clinicians to living tissue is a concept 
that has the potential to create a great impact on the future treatments. One of the major obstacles to the proper functioning of the tissue outside the body is to understand the way in which cells can be set in niches under certain physical and chemical conditions which would be difficult $[8,9]$. In this case, bioreactors can control the situation and imitate the natural environment. Bioreactor devices can control and adjust the physiological conditions. With advances in tissue engineering, scaffold design could put several layers of cells onto scaffolds for three-dimensional position. That purpose requires a microenvironment for growth in vitro. The mathematical model was able to calculate the fluid flow rate for scaffold to provide nutrients and remove wastes and release oxygen used. As well as other variables such as external mechanical force needed to stimulate the proliferation of osteoblasts and then followed it can also be provided. Another alternative method that involves the cultivation of graft in vivo using animal models or humans as a bioreactor to simulate the growth of cells is provided. The remainder of this chapter presents various examples discussed regarding various tissues of the jaw and face [9].

\section{Oral and maxillofacial bone defects}

\subsection{Mandibular defects}

The atrophic mandible presents its own unique set of challenges in reconstructive maxillofacial surgery. A mandibular vertical height of less than $2 \mathrm{~cm}(20 \mathrm{~mm})$ is universally considered atrophic and presents with characteristic anatomic and physiologic features, such as hypovascularity, which might contribute to tooth and alveolar process loss. The atrophic resorption patterns also contribute to the consistent anatomic changes, such as prominent mylohyoid and internal oblique ridges, which are covered with a thin mucosal lining, contributing to an increased risk of soft tissue breakdown and dehiscence. These anatomic changes happen secondary to a deficiency in blood supply from the lack of muscle attachments in those areas, whereas the areas that have a healthy musculature show an increased blood supply, making it more resistant to postdental extraction resorption. An important concept that reconstructive surgeons need to understand is that atrophic mandibles depend heavily on periosteal blood supply because of the narrowing of the inferior alveolar artery [10-12].

Cawood and his group from the United Kingdom found that alveolar bone resorption seemed to have a predictable pattern:

- Class I, dentate

- Class II, immediately post-extraction

- Class III, well-rounded ridge form, adequate in height and width

- Class IV, knife-edge ridge form, adequate in height and inadequate in width

- Class V, flat ridge form, inadequate in height and width

- Class VI, depressed ridge form, with some basilar bone loss evident [13] 
This classification has more relevance to implant dentistry because it gives the operator an idea of whether an adjunctive bone graft would be necessary (classes IV and V).

Marx and colleagues [14] published a novel soft tissue matrix expansion also known as the "tent pole," where the dental implants effectively "tent" the soft tissue envelope up to maintain the bone graft volume and prevent soft tissue collapse. The original description used an extraoral submental approach, and the bone graft material of choice was the anterior iliac crest bone graft, with four to five implants placed (each one $15 \mathrm{~mm}$ in height), with a 1-cm interimplant distance. Primary stability was obtained by engaging the inferior border of the mandible with the implants. Autogenous corticocancellous bone graft is then packed around the implants.

Patel et al. reported that the addition of rhBMP in the tent pole technique had a favorable impact on bone healing and allowed substitution of the posterior iliac crest as a donor site with the anterior iliac crest bone graft because of the enhanced osteoinduction that happens with rhBMP. Furthermore, the authors rarely use the classical anterior iliac crest bone grafting approach, instead opting for the trephine to harvest the bone from the anterior iliac crest, with excellent increase in vertical bone height and final implant placement. This translated to less donor-site morbidity and earlier mobilization [15].

Many surgeons have modified Marx's original tent pole technique, and some have replaced dental implants with bone screws; this modification seemed to improve the buccolingual orientation of the final implant placement, because the dental implants would be placed at a second procedure, when all of the bones have been consolidated, and the position of the implants is more ideal. A second advantage of this modification is that it allows the use of surgical implant guides, especially if a maxillary prosthesis exists. Another commonly used method is the use of a titanium mesh to tent the soft tissue and maintain the bone graft and the contour of the ridge. However, the main disadvantage of this technique is that the surgical site must be reentered to remove the titanium mesh before implant placement. This has presented its own set of challenges, especially when the graft grows over the mesh, and the procedure requires excessive soft tissue reflection.

Another bioactive agent that has been studied in maxillofacial reconstructive surgery is recombinant human platelet-derived growth factor. This is a product of platelets and functions as a chemotactic and mitogenic factor for osteoblasts and is critical for angiogenesis and thus can be applied to treating ridge defects [16]. This growth factor has been combined with several different types of grafting materials and carriers, such as mineralized and demineralized FDBA [17], xenograft (specifically deproteinized bovine block graft), equine block graft [18], and bTCP [19], in multiple case series and has been shown to help produce intact woven and lamellar bone contributing to an increase in vertical ridge height in humans, which was of appropriate quality to accommodate the placement of dental implants at a second stage. The concept of engineered heterotopic bone formation has also been studied; however, this has not yet gained much notoriety. In 2004, it was studied in the reconstruction of large segmental mandibular defects by way of an engineered growth of a mandibular transplant within a muscular environment (in this case the latissimus dorsi muscle) with the help of BMPs, with subsequent free tissue transfer of the bone-muscle flap approximately 7 weeks later [20]. 
A prefabricated titanium mesh was filled with bone mineral blocks, BMPs, and the patient's own bone marrow. Although a clinically successful result was obtained, this procedure may not be as cost-effective as some of the more traditional and established methods of free tissue transfer for mandibular reconstruction and does carry with it significant morbidity related to the surgery itself and potential complications, such as brachial plexus injury and shoulder drop [21]. Nonetheless, it certainly does open up a different aspect of tissue engineering and strategies for maxillofacial reconstruction [22, 23].

\subsection{Maxillary sinus augmentation}

It is challenging to reconstruct the edentulous posterior maxilla with dental implants due to insufficient bone height after crestal bone resorption and also maxillary sinus pneumatization [24, 25]. In recent years, with aid of existing space in the maxillary sinus, clinicians introduced techniques for surgical augmentation that use to restore bone height and also create a sufficient implant bed area which seems to resolve patient's treatment difficulties $[26,27]$. Researchers suggested a variety of modifications in original sinus augmentation technique to ease different difficulties for clinicians and also patients [28, 29], but the basic principle of each technique remained unchanged which is to increase maxillary bone height with aid of placing graft material in the maxillary sinus after attending to detach the sinus membrane $[25,28,29]$. Nowadays, for rehabilitation of the posterior maxilla with dental implants, the use of maxillary sinus augmentation (MSA) is considered as a standard procedure $[24,25]$.

In original technique, before dental implant insertion, MSA was performed with the autogenous bone $[25,30]$. Autogenous bone has usually been cited as the most eligible material to achieve predictable and favorable results in MSA. It is due to the fact that autogenous bone contains living cells and growth factors which cause osteogenic ability [25, 30]. In contrast, it should have been noticed that available supplies for autogenous bone are limited. Also, as disadvantage, harvesting autogenous bone is painful and includes procedures with risk of infection. With these in mind, it is necessary to investigate and develop alternative techniques to overcome these drawbacks [24, 25, 31-37].

Introduction of different osteoconductive biomaterials such as allogeneic bone [31, 32], xenogeneic bone [32-34], or alloplastic or composite materials [34, 35] which are cell-free and due to that require more time for bone healing. This is a disadvantage that none of mentioned materials have biological and structural properties similar to the native bone [24, 25, 34-37].

The modern science of bone tissue engineering, a fusion of recent discoveries in the field of molecular cell biology with the most innovative methods of reconstructive surgery, aims to overcome these boundaries [38].

In Table 1, studies of stem cell approach for tissue engineering dealing with sinus augmentation were illustrated.

A major disadvantage of potential bone substitutes is their inherent slow ability to induce new bone at a foreseeable rate. By advances and innovation in technology in tissue engineering, introduced alternative materials which are used as bone show significant advantages in 


\begin{tabular}{|c|c|c|c|c|c|c|}
\hline Study & Control & Type SC & Scaffold & Evaluation & Follow-up & Complications \\
\hline Gonshor et al. & Allograft & $\begin{array}{l}\text { MSC (bone } \\
\text { marrow) }\end{array}$ & $\begin{array}{l}\text { Allograft } \\
\text { (Osteocel) }\end{array}$ & $\begin{array}{l}\text { Histology after } \\
3-4 \text { months }\end{array}$ & & None \\
\hline Voss et al. & ABG & $\begin{array}{l}\text { MSC } \\
\text { (periosteum) }\end{array}$ & Polymer fleece & $\begin{array}{l}\text { Radiography, } \\
\text { histology on } 18 \\
\text { patients }\end{array}$ & 24 months & A \\
\hline Shayesteh et al. & None & $\begin{array}{l}\text { MSC (bone } \\
\text { marrow) }\end{array}$ & $\mathrm{HA} / \mathrm{TCP}$ & $\begin{array}{l}\text { Histology after } \\
3 \text { months }\end{array}$ & 12 months & None \\
\hline Yamada et al. & None & $\begin{array}{l}\text { MSC (bone } \\
\text { marrow) }\end{array}$ & PRP & Radiography & $\begin{array}{l}\text { 2- to } \\
6.3 \text {-year }\end{array}$ & None \\
\hline Rickert et al. & $\begin{array}{l}30 \% \mathrm{ABG} \\
\text { and } 70 \% \\
\mathrm{BBM}\end{array}$ & $\begin{array}{l}\text { MSC (bone } \\
\text { marrow) }\end{array}$ & BBM & $\begin{array}{l}\text { Histology after } \\
\text { 13-16 weeks }\end{array}$ & & None \\
\hline $\begin{array}{l}\text { Schimming } \\
\text { et al. }\end{array}$ & None & $\begin{array}{l}\text { MSC } \\
\text { (periosteum) }\end{array}$ & Polymer fleece & $\begin{array}{l}\text { Histology after } \\
3 \text { months }\end{array}$ & $\begin{array}{l}6 \text { months in } \\
9 \text { patients }\end{array}$ & B \\
\hline $\begin{array}{l}\text { MacAllister } \\
\text { et al. }\end{array}$ & None & $\begin{array}{l}\text { MSC (bone } \\
\text { marrow) }\end{array}$ & $\begin{array}{l}\text { Allograft } \\
\text { (Osteocel) }\end{array}$ & $\begin{array}{l}\text { Histology after } \\
4 \text { months }\end{array}$ & & None \\
\hline Mangano et al. & $\begin{array}{l}\text { Calcium } \\
\text { phosphate }\end{array}$ & $\begin{array}{l}\text { MSC (bone } \\
\text { marrow) }\end{array}$ & Polymer fleece & $\begin{array}{l}\text { Histology after } \\
6 \text { months, CT } \\
\text { scan }\end{array}$ & & $\mathrm{C}$ \\
\hline $\begin{array}{l}\text { Zizelmann } \\
\text { et al. }\end{array}$ & $\mathrm{ABG}$ & $\begin{array}{l}\text { MSC } \\
\text { (periosteum) }\end{array}$ & Polymer fleece & $\begin{array}{l}\text { Radiography } \\
\text { after } 3 \text { months }\end{array}$ & & $\mathrm{D}$ \\
\hline Ueda et al. & None & $\begin{array}{l}\text { MSC (bone } \\
\text { marrow) }\end{array}$ & PRP & Radiography & $2-5$ years & None \\
\hline Sauerbier et al. & $\begin{array}{l}\text { MSC (bone } \\
\text { marrow) vs. } \\
\text { BMAC }\end{array}$ & $\begin{array}{l}\text { MSC (bone } \\
\text { marrow) }\end{array}$ & BBM & $\begin{array}{l}\text { Histology after } \\
3 \text { months }\end{array}$ & 12 months & None \\
\hline Fuerst et al. & None & $\begin{array}{l}\text { Autogenous } \\
\text { culture-expanded } \\
\text { bone cells }\end{array}$ & BBM & $\begin{array}{l}\text { Histology after } \\
6 \text { months }\end{array}$ & & None \\
\hline $\begin{array}{l}\text { Trautvetter } \\
\text { et al. }\end{array}$ & None & $\begin{array}{l}\text { MSC } \\
\text { (periosteum) }\end{array}$ & Polymer fleece & $\begin{array}{l}\text { Histology after } \\
6 \text { months }\end{array}$ & 5 years & None \\
\hline $\begin{array}{l}\text { Schmelziesen } \\
\text { et al. }\end{array}$ & None & $\begin{array}{l}\text { MSC } \\
\text { (periosteum) }\end{array}$ & Polymer fleece & $\begin{array}{l}\text { Histology after } \\
4 \text { months }\end{array}$ & & None \\
\hline Hermund et al. & $\begin{array}{l}50 \% \\
\mathrm{ABG}+50 \% \\
\mathrm{BBM}\end{array}$ & $\begin{array}{l}\text { Autogenous } \\
\text { culture-expanded } \\
\text { bone cells }\end{array}$ & $\begin{array}{l}50 \% \text { ABG }+50 \% \\
\mathrm{BBM}\end{array}$ & $\begin{array}{l}\text { Histology after } \\
4 \text { months }\end{array}$ & 8 months & None \\
\hline Sauerbier et al. & $\begin{array}{l}30 \% \\
\mathrm{ABG}+70 \% \\
\mathrm{BBM}\end{array}$ & $\begin{array}{l}\text { MSC (bone } \\
\text { marrow) }\end{array}$ & BBM & $\begin{array}{l}\text { Histology after } \\
3-4 \text { months }\end{array}$ & & None \\
\hline Springer et al. & BBM & $\begin{array}{l}\text { MSC } \\
\text { (periosteum) } \\
\text { (1) Autogenous } \\
\text { culture-expanded } \\
\text { bone cells (2a) }\end{array}$ & $\begin{array}{l}\text { Collagen [1] } \\
\operatorname{BBM}(2 a)\end{array}$ & $\begin{array}{l}\text { Histology after } \\
6-8 \text { months }\end{array}$ & & None \\
\hline
\end{tabular}




\begin{tabular}{lllllll}
\hline Study & Control & Type SC & Scaffold & Evaluation & Follow-up & Complications \\
\hline $\begin{array}{l}\text { Beaumont } \\
\text { et al. }\end{array}$ & None & $\begin{array}{l}\text { MSC } \\
\text { (periosteum) }\end{array}$ & $\begin{array}{l}\text { BBM + polymer } \\
\text { fleece }\end{array}$ & $\begin{array}{l}\text { Histology after } 4 \\
\text { and 6 months }\end{array}$ & 18 months & None \\
\hline
\end{tabular}

Adopted from Jakobsen et al. [39]

BBM, bovine bone mineral; HA/TCP, hydroxyapatite/tricalcium phosphate; NA, data not available; MSCs, mesenchymal stem cells; PRP, platelet-rich plasma; RCT, randomized clinical trial

A: 11 augmentations failed in test group, none in control group

B: Histology shows little or no bone formation in 8 of 15 patients, when a two-stage protocol was used.

C: Less bone and more medullar spaces were found in test group compared with control group.

D: 13 of 14 sinuses showed insufficient bone formation. Resorption $90 \%$ in test group after 3 months, $29 \%$ in control group

Table 1. Studies regarding cell-based sinus lift procedure.

their bone-inductive capabilities. These results are similar to the result of study conducted by Neiva et al., which revealed favorable outcomes with the use of PepGen P-15 Putty. They conclude this result from initial osteogenesis of intervened group which is guided by the putty and achieved an additional mature trabecular pattern in shorter period of time comparing to the control group. Earlier bone formation is evaluated and revealed in 3D radiographic assessment as early as 8 weeks [40].

A variety of study designs used in cellular studies on sinus grafting techniques outcome the square measure constituent. Briefly, most studies comparing cell therapy with a traditional grafting technique showed similar results [41-44].

\subsection{Dorsal augmentation in rhinoplasty}

As application of allografts for dorsal augmentation seems to have serious disadvantages [45], it appears that we might tend to observe the appliance of tissue engineering in rhinoplasty; Kim et al. in 2014 within the article made a case for the chondrocytes and porcine cartilage substance (PCS) construct as an attainable dorsal augmentation material in rhinoplasty cultured with a porcine cartilage-derived substance (PCS) scaffold as a potential substitute for normal tissue use for augmentation in rhinoplasty. A scaffold is derived from decellularized and fine-grained porcine articular cartilage prepared. The use of the rabbit articular cartilage was due to ability to supply homologous chondrocytes, which for 7 weeks were enlarged and polite with the PCS scaffold. The chondrocyte-PCS constructs were then surgically implanted on the nasal dorsum of six rabbits. Four and 8 weeks after implantation, complete evaluations such as the gross morphology, radiologic pictures, and microscopic anatomy options of the location of implant were analyzed. The rabbits showed no signs of surgical inflammation and infection. The degree of dorsal augmentation was maintained throughout the 8-week surgical observation amount. Surgical examinations showed chondrocyte proliferation while there was no inflammatory response. However, neo-cartilage formation from the constructs was not confirmed. The biocompatibility and structural options of tissue-engineered chondrocytePCS constructs indicate their potential as candidate dorsal augmentation material to be used in rhinoplasty [46]. 
Cultured chondrocytes and porcine cartilage substance (PCS) constructs as an attainable dorsal augmentation material in rhinoplasty: preliminary animal study and, additionally Mendelson et al. in 2014 conferred this concept than designed nasal cartilage by cell homing: a model for augmentative and rehabilitative rhinoplasty. Bioactive scaffolds were developed that not solely recruited cells within the nasal dorsum in vivo, however, additionally induced chondrogenesis of the recruited cells. Bilayered scaffolds were fictional with alginate-containing gelatin microspheres encapsulating cytokines atop a porous poly(lactic-co-glycolic acid) base. Microspheres were fictional to contain recombinant human remodeling growth factor $\beta 3$ at doses of 200, 500, or $1000 \mathrm{ng}$, with phosphate-buffered saline-loaded microspheres used as a bearing. A rat model of augmentation facelift was created by implanting scaffolds atop the native nasal cartilage surface that was scored to induce cell migration. Tissue formation and chondrogenesis within the scaffolds were evaluated by image analysis and microscopic anatomy staining with hematoxylin and eosin, toluidine blue, Verhoeff elastic-van Gieson, and aggrecan immunohistochemistry. Sustained release of increasing doses of remodeling growth factor $\beta 3$ for up to the tested 10 weeks promoted orthotopic cartilage-like tissue formation in an exceedingly dose-dependent manner. It appears that these findings represent the primary commitment to engineer cartilage tissue by the cell orientating for facelift and will doubtlessly function as an alternate material for augmentative and rehabilitative rhinoplasty [46].

An important feature for rehabilitative and augmentative rhinoplasty is the ability of the graft to be tailored to the individual patient. Autologous graft area unit is stacked and sutured along in a very bundle before implantation. The bioactive poly(lactic-co-glycolic acid) scaffolds are simply changed to larger augmentations by varied the mold diameter wont to create the poly(lactic-co-glycolic acid) scaffold base. For associate degree off-the-shelf product, three totally different scaffolds can be generated with a variety of forms and sizes and simply cut for precise adjustments. Thus, the bioactive scaffolds might probably be used as completely unique various implant styles to current rhinoplasty treatment [46].

\section{Skin}

It seems that one of the important years for tissue engineering is 1975; in this year, some occurrence about skin engineering was evolved in this field even though the Washington National Science Foundation applied science panel meeting to formally adopt the term "tissue engineering" for this field a decade later in 1987 [47] and Langer and Vacanti explained the definition of this field later in 1993 [1]. The first step is ascribed to the actions of two teams in the United States 40 years ago. Rheinwatd and Green were the first team who are unskilled and ignored cultivation of human epidermal keratinocytes in vitro [48]; they also created potentially the enlargement of those cultivation of cells into numerous epithelial cells for graft in 1975 [49] from a little skin diagnostic assay. Today, the work that was done in those days is called "skin epidermis tissue engineering." At the same time, Yannas et al. worked on the features of scleroprotein and degradation mechanism [50] in 1975, which now 
we believe that these efforts facilitate the way for the new generation of artificial dermal substitute, resulting in the "skin dermis tissue engineering" [51]. Fortunately, after 6 years, both of these groups independently revealed the clinical effect of tissue-engineered substitutes for the treatment of different grade burns, albeit in different approaches. The first graft of extensive burns with sheets of cultured epithelium (produced from epidermal cells which are autologous) was reported by $\mathrm{O}^{\prime} \mathrm{C}$ onnor et al., two adult patients were experienced at the Peter Bent Brigham Hospital [52, 53]. Cultured epidermal autografts (CEA) were the next generation of cultured sheets which are autologous and also successively revealed to prepare cover of full-thickness burns in pediatric patients [54]. Meantime, only a short time after O'Connor et al.'s study, Burke et al. revealed that artificial dermis had experienced functional and physiological acceptable dermis in the treatment of extensive full-thickness burns on several patients [55]. These evidences resulted in randomized clinical trial for extensive burn injuries led by Heimbach et al. [56] about the application of artificial dermis; now new generation of artificial dermis is known as IntegraTM Dermal Regeneration Template. This study was done successfully by collaborating 11 centers, and other studies $[57,58]$ could inevitably demonstrate this dermal substitute a "gold standard" material treatment of fullthickness burns [59].

But there are still challenges, and those two groups are still far from reaching the final goal of replacing autologous skin for coverage of permanent deep dermal or full-thickness injuries in extensive burns.

Table 2 demonstrates the current status of available tissue-engineered materials and techniques for skin substitution.

\begin{tabular}{|c|c|c|c|c|}
\hline & $\begin{array}{l}\text { Skin substitute/ } \\
\text { surgical technique }\end{array}$ & Structure & Advantage & Disadvantage \\
\hline \multirow[t]{4}{*}{ Epidermal } & $\begin{array}{l}\text { Cultured epithelial } \\
\text { autograft (CEA) }\end{array}$ & $\begin{array}{l}\text { Confluent autologous } \\
\text { keratinocytes }\end{array}$ & $\begin{array}{l}\text { In vitro } \\
\text { expansion for } \\
\text { large bum area, } \\
\text { permanent }\end{array}$ & $\begin{array}{l}\text { Fragility, infection, high } \\
\text { cost, and variable take } \\
\text { rate }\end{array}$ \\
\hline & CUONO's method & & Extensive bums & $\begin{array}{l}\text { Two-stage procedure, } \\
\text { precise grafting time } \\
\text { coordination }\end{array}$ \\
\hline & $\begin{array}{l}\text { CEA with meshed } \\
\text { split-thickness skin } \\
\text { autograft }\end{array}$ & & $\begin{array}{l}\text { Expansion 1:4, } \\
\text { no rejection }\end{array}$ & $\begin{array}{l}\text { Beyond 1:4 expansion: } \\
\text { poor cosmetic } \\
\text { and functional } \\
\text { results, delayed } \\
\text { reepithelialization }\end{array}$ \\
\hline & $\begin{array}{l}\text { CEA with } \\
\text { microskin } \\
\text { autograft }\end{array}$ & & $\begin{array}{l}\text { Expansion } \\
\text { 1:9-15, no } \\
\text { rejection, high } \\
\text { take rate, shorter } \\
\text { epithelization } \\
\text { time }\end{array}$ & $\begin{array}{l}\text { Time-consuming, labor- } \\
\text { intensive, hypertrophic } \\
\text { scarring }\end{array}$ \\
\hline
\end{tabular}




\begin{tabular}{|c|c|c|c|c|c|}
\hline & & $\begin{array}{l}\text { Skin substitute/ } \\
\text { surgical technique }\end{array}$ & Structure & Advantage & Disadvantage \\
\hline \multirow[t]{11}{*}{ Dermal } & $\begin{array}{l}\text { Artificial } \\
\text { biological } \\
\text { materials }\end{array}$ & Integra $^{\mathrm{TM}}$ & $\begin{array}{l}\text { Cross-linked bovine } \\
\text { tendon collagen-based } \\
\text { dermal matrix linked with } \\
\text { glycosaminoglycan (GAG) }\end{array}$ & & $\begin{array}{l}\text { Two-stage procedure, } \\
\text { infection, hematomas, } \\
\text { seromas }\end{array}$ \\
\hline & & $\begin{array}{l}\text { Integra }^{\mathrm{TM}} \text { with } \\
\text { CEA }\end{array}$ & & $\begin{array}{l}\text { Good long- } \\
\text { term esthetic } \\
\text { and functional } \\
\text { outcome }\end{array}$ & High cost, poor adhesion \\
\hline & & $\begin{array}{l}\text { Integra }^{\mathrm{TM}} \text { with } \\
\text { Meek }\end{array}$ & & & \\
\hline & & MatriDerm ${ }^{\circledast}$ & $\begin{array}{l}\text { Bovine non-cross-linked } \\
\text { lyophilized dermis, } \\
\text { coated with alpha-elastin } \\
\text { hydrolysate }\end{array}$ & & \\
\hline & & $\begin{array}{l}\text { Composite skin } \\
\text { substitute }\end{array}$ & $\begin{array}{l}\text { MatriDerm as a template, } \\
\text { seeded with expanded } \\
\text { autologous skin fibroblast } \\
\text { and keratinocytes }\end{array}$ & $\begin{array}{l}\text { Full wound } \\
\text { closure }\end{array}$ & \\
\hline & & Blobrane $^{\circledast}$ & $\begin{array}{l}\text { Silicone membrane and } \\
\text { nylon mesh impregnated } \\
\text { with porcine dermal } \\
\text { collagen }\end{array}$ & $\begin{array}{l}\text { One-stage } \\
\text { procedure, } \\
\text { coverage of } \\
\text { partial-thickness } \\
\text { bums }\end{array}$ & $\begin{array}{l}\text { Intolerant to } \\
\text { contaminated wound bed }\end{array}$ \\
\hline & $\begin{array}{l}\text { Natural } \\
\text { biological }\end{array}$ & AlloDerm $^{\circledast}$ & $\begin{array}{l}\text { Human acellular } \\
\text { lyophilized dermis }\end{array}$ & $\begin{array}{l}\text { Acellular, } \\
\text { immunologically } \\
\text { inert, provide } \\
\text { natural dermal } \\
\text { porosities for } \\
\text { regeneration and } \\
\text { vascularization } \\
\text { on the wound } \\
\text { bed }\end{array}$ & $\begin{array}{l}\text { High cost, risk of } \\
\text { transmitting disease, } \\
\text { two-stage procedure }\end{array}$ \\
\hline & & $\begin{array}{l}\text { AlloDerm }{ }^{\circledast} \text { with } \\
\text { CEA }\end{array}$ & & & Multiple applications \\
\hline & & Permacol $^{\mathrm{TM}}$ & $\begin{array}{l}\text { Porcine acellular } \\
\text { lyophilized dermis }\end{array}$ & $\begin{array}{l}\text { Good esthetic } \\
\text { and functional }\end{array}$ & $\begin{array}{l}\text { Infection, hematomas, } \\
\text { seromas }\end{array}$ \\
\hline & $\begin{array}{l}\text { Synthetic } \\
\text { materials }\end{array}$ & TransCyte ${ }^{\circledR}$ & $\begin{array}{l}\text { Porcine collagen-coated } \\
\text { nylon mesh seeded with } \\
\text { allogeneic neonatal human } \\
\text { foreskin fibroblasts }\end{array}$ & $\begin{array}{l}\text { Immediate } \\
\text { availability, ease } \\
\text { of storage }\end{array}$ & Temporary \\
\hline & & Dermagraft ${ }^{\circledR}$ & $\begin{array}{l}\text { Bioabsorbable polyglactin } \\
\text { mesh scaffold seeded with } \\
\text { cryopreserved allogeneic } \\
\text { neonatal human foreskin } \\
\text { fibroblasts }\end{array}$ & $\begin{array}{l}\text { Ease of } \\
\text { handling, no } \\
\text { rejection, chronic } \\
\text { wounds- } \\
\text { diabetic ulcers }\end{array}$ & $\begin{array}{l}\text { Poor ECM structure, } \\
\text { infections, cellulitis, }\end{array}$ \\
\hline
\end{tabular}




\begin{tabular}{|c|c|c|c|c|}
\hline & $\begin{array}{l}\text { Skin substitute/ } \\
\text { surgical technique }\end{array}$ & Structure & Advantage & Disadvantage \\
\hline \multirow[t]{2}{*}{ Dermo-epidermal } & PermaDerm $^{\mathrm{TM}}$ & $\begin{array}{l}\text { Collagen- } \\
\text { glycosaminoglycan } \\
\text { substrates containing } \\
\text { autologous fibroblasts and } \\
\text { keratinocytes }\end{array}$ & $\begin{array}{l}\text { Permanent } \\
\text { replacement } \\
\text { of both dermal } \\
\text { and epidermal } \\
\text { layers, one-step } \\
\text { procedure }\end{array}$ & $\begin{array}{l}\text { No clinical trial reported } \\
\text { yet }\end{array}$ \\
\hline & DenovoSkin & $\begin{array}{l}\text { Plastically compressed } \\
\text { collagen type } 1 \text { hydrogels } \\
\text { engineered with human } \\
\text { keratinocytes and } \\
\text { fibroblasts }\end{array}$ & $\begin{array}{l}\text { Near-normal } \\
\text { skin architecture }\end{array}$ & $\begin{array}{l}\text { Long culture time, no } \\
\text { clinical series reported } \\
\text { yet }\end{array}$ \\
\hline
\end{tabular}

Adopted from Chua et al. [60]

Table 2. Tissue-engineered materials and current surgical techniques for skin substitution.

The happen which facilitates efforts is that combination between a skin allograft bank and professional laboratory which culture autologous epithelial cell sheet could be an important step, and also we should gather many scientists and engineers and absorb finance in this field. The only way that can create the demand of engineered tissue for patients is through working and collaborating with clinicians, and also this expert team brings us innovation, novel technologies, and cost management and realizes the challenges in advancement of skin tissue engineering [61-65].

\section{Oral mucosa}

There is a recognized lot to reconstruct and restore advanced craniomaxillofacial (CMF) soft tissues that are broken and/or disfigured as a consequence of automobile accident, trauma, burn injury, or tumor surgery. In trauma, injuries usually produce extraordinarily advanced geometric and avulsion defects, and also the anatomic and purposeful intricacies of CMF composite soft tissue structures like the lips, eyelids, and nasal advanced create the reconstruction significantly difficult for maxillofacial surgeons (Table 3).

Kenji Izumi et al. in 2013 within the article evaluated the appliance of tissue engineering in oral mucosa [67]; the first objective of this study was to gauge the security of a tissueengineered human ex vivo produced oral mucosa equivalent (EVPOME) in intraoral graft procedures. The secondary objective was to assess the efficacy of the grafted EVPOME in manufacturing a keratinized mucosal surface epithelial tissue. Five patients World Health Organization based on inclusion criteria that defects in mucogingival region or an absence of gingiva which is keratinized on incisors and premolars teeth, together with radiographies of adequate bone height in interdental region, were used to expand the amount of keratinized gingiva in the defect site. A specimen was taken by a punch biopsy from hard palate to accumulate oral keratinocytes, which were enlarged, associate degreed cultured on associate degree noncellular matrix of the dermis for make of an EVPOME. 


\begin{tabular}{lll}
\hline Approach & Advantages & Disadvantages \\
\hline $\begin{array}{l}\text { Free grafts (full-thickness } \\
\text { skin grafts, split-thickness } \\
\text { skin grafts, etc.) }\end{array}$ & $\begin{array}{l}\text { Simply harvested, vital tissue } \\
\text { accessibility }\end{array}$ & $\begin{array}{l}\text { Poor color match, donor-site morbidity, lack of } \\
\text { bulk, no performance }\end{array}$ \\
$\begin{array}{l}\text { Local advancement and } \\
\text { motility flaps }\end{array}$ & Sensible color match, functional & $\begin{array}{l}\text { Restricted quantity, might need staged surgeries, } \\
\text { will result in microstomia and associated } \\
\text { purposeful deficits in speech and swallowing }\end{array}$ \\
$\begin{array}{l}\text { Free vascularized tissue } \\
\text { transfer }\end{array}$ & $\begin{array}{l}\text { Wonderful tube peduncle, } \\
\text { applicable tissue thickness, and a } \\
\text { technique to suspend the lip with } \\
\text { the incorporated tendon } \\
\text { Sensible color match, purposeful }\end{array}$ & $\begin{array}{l}\text { Long recovery, donor-site morbidity, lack of } \\
\text { performance, poor color match/esthetics, needs } \\
\text { specialized surgical skills }\end{array}$ \\
tissue, esthetics & $\begin{array}{l}\text { Needs long immunosuppression, facet effects } \\
\text { of immunosuppression, long and troublesome } \\
\text { recovery, donor accessibility, needs specialized } \\
\text { face transplant }\end{array}$ & $\begin{array}{l}\text { surgical skills and facility } \\
\end{array}$ \\
\hline
\end{tabular}

Table 3. The advantages and downsides of the contemporary approach to soft tissue reconstruction [66].

EVPOME grafts have special features which are used directly over associate degree healthy periosteal bed and preserved in situ. At 1 and at 7, 14, 30, 90, and 180 days postsurgery, Plaque Index and Gingival Index were recorded for every subject. Additionally, inquisitory depths, keratinized animal tissue dimension, and keratinized animal tissue thickness were recorded at baseline, 30, 90, and 180 days. Fortunately, there were no adverse outcomes or complications to EVPOME ascertained in all cases throughout the research. But the mean increased in keratinized animal tissue dimension was $3 \mathrm{~mm}$ (range, 3-4 mm), and no vital changes in depths were ascertained. According to our findings, we can terminate that EVPOME is useful for oral application and has the flexibility to reinforce keratinized gingiva. More randomized clinical trials in this field should be performed to demonstrate other dimensions of tissue engineering [67].

The maintenance of associate degree sufficient strip of attached gingiva includes a minimum of $2 \mathrm{~mm}$ of keratinized gingiva and has revealed that it could be necessary for preservation of periodontal tissue $[68,69]$. Historically, FGGs' associate degreed grafts which were taken from connective tissue are applied to gain sufficient strip of attached gingiva [70]. Unfortunately, clinical evidence about the use of autologous and allogenic products confronts to some problems about FGGs, i.e., problems about morbidity around donor region and also amount of tissue for graft which is restricted [71]. Nevins [72] applied treatment by bilayered cell for mucogingival region, and this research revealed that adequate keratinized tissue was gained; however, the amount was not more than it gained with FGGs. Interestingly, each research tried to prove that clinical evidence such as texture and color have better results when compared with FGGs. Nevertheless, application of products that have allogenic cells could have important effect on the wound bed; the impact of treatment could be as a completely unique "biologic dressing" to motivate encompassing cells. One of the reliable materials was a scaffold which is biodegradable with gingival autologous fibroblasts which are cultured [73]. Another research in this field used oral mucosa cells to transplant directly to the cornea [74]. 
Another researchers believed that the long time (more than 22 months) existence of the cultured keratinocytes from oral cavity, expressed markers of stem cell. Also evidence tried to by pharmacologic approach produce cultured oral keratinocytes to produce stem cell population; and now all efforts focus on clinical application of this technology that has a lot of simply for the event of a lot of strong EVPOME for intraoral graft procedures [75]. As a result of oral mucosa keratinocyte area unit simply getable and expand quicker in vitro than skin keratinocytes [76], they will be a lot of efficacious to be used in future clinical applications in regenerative medicine. This platform technique might produce other potential extraoral uses, like repair of facial skin [77], reconstruction of eyelids and nose, or in situ tissue layer substitutes for the urethra and conjunctiva [78].

\section{Temporomandibular joint disorders}

The temporomandibular joint (TMJ) may be a synovial joint that has for articulator motion relative to the os base and distributes the traditional stresses of perform (chewing and speaking) and parafunction (clenching and bruxism). It is usually noted as ginglymoarthrodial joint attributable to its slippy performance and hinging. The temporomandibular joint links the condyloid process (mandibular bone) to the temporal bone. The cartilage disc is the middle of mandibular condyle and the glenoid fossa eminence of the temporal bone and separates the joint area into inferior and superior compartments, each of that area unit crammed with synovial fluid [79].

Because of the advanced loading patterns that designed tissues can expertise within the TMJ, acquisition of complete style parameters from the native tissue is important. Significantly, TMJ disc, condyle, and condylar cartilage replacement area unit in nice demand attributable to these tissues' poor regenerative capability and high rate of involvement in TMD. In response, many studies characterizing the properties of those elements are performed [79]. Though glenoid fossa and articular eminence are the concern in TMD, they need not be absolutely characterized. Within the following section, structural characteristics of the TMJ tissue area unit are summarized. Application of tissue engineering in the treatment of temporomandibular joint defects is rising as a progressive choice to substitute and remove the pathological defects automatically in the near future. Historically, basics of regenerative medicine are three necessary elements, cells, stimulator factors, and scaffolds. But new technology introduced novel methodologies and recommends how to manage TMJ disk and stimulate relevant cartilage [80]. This approach includes the scaffold-free and cell-based methodology and cells and stimulators that work together. But another approach is to construct a structure and render appropriate form of engineered tissues, permitting well-designed structure and simple handling [81]. Another mechanical feature may be appropriate for designed tissue. In the best manner the chemistry of scaffold that could be degradation with matrix synthesis. But the rate of scaffold degradation depends on the nature of scaffold and might be modified by manipulation. For induction of the mass of matrix synthesis, growth factors are added to the scaffolds. Today, all engineered tissue materials are used to regenerate condyle and TMJ disc; however, similar strategies for regeneration of mandibular fossa are not successful [82]. 


\section{Conclusion}

Unfortunately, limiting factors still existed; most of them could be the differences of lab environment and human body such as unknown exact dose of BMP and applicate high dose of this material to creation of bony scaffold [83]. On the other hand, unpredictable effects of BMP and complications about application of BMP together with oncogenesis. Based on these evidences, Food and Drug Administration (FDA) restricted application of BMP to sinus alveolar process augmentation in the United States; other substitute materials in maxillofacial region should be considered moral issues even if these materials reveal high level of evidence in several experimentations [84].

Another problem like tissue transfer decreases the chance of high-quality and priced experimentations [85], and also Ripamonti et al. study revealed that growth factor and signaling systems in animal and human are totally different and huge variation between them is observed. Unfortunately, there are few clinical trials in the maxillofacial region, but the question is what the obstacles are? The main obstacles are how to predict regenerate cells to not become oncogenesis and produce our wanted cells, how to manage signaling factors to facilitate the procedure of regeneration, and how to create the scaffold that permits cell growth in the best way. More clinical trials are needed to remove the obstacles [86].

Tissue engineering is the field that is surrounded by other fields like histology, medical engineering, and pathology that every progress in these fields could change principles of tissue engineering. Our goals are simple which are to know how to regenerate human tissues from host cells and somehow that these regenerates have desirable function and esthetics. To reach to this goal, we have long way, but today engineers progressed biocompatible scaffolds, increase the flexibility to $3 \mathrm{D}$ tissue constructs, and designed complex tissue for the different facial areas. The latest progress guarantees that tissue engineering is the trustworthy choice for the treatment of maxillofacial defects. In future, the role of tissue engineering will increase and become routine in surgeries.

\section{Acknowledgements}

Conducting this review will not be possible without team work and cooperation. We have to thank people for their work in helping us through this way, authors of all referenced articles which are used for construction of this review, Dr. Tannaz Tafakori, Eng. MT AmirzadeIranaq, and Mr. MS Amirzade-Iranaq with their search and companionship.

\section{Conflict of interest}

Authors declare that there is no conflict of interest that may damage the integrity and validity of this research. 


\section{Author details}

Seied Omid Keyhan ${ }^{1,2,3,4}$, Hamidreza Fallahi ${ }^{5}$, Alireza Jahangirnia ${ }^{6}$,

Seyed Mohammad Reza Masoumi ${ }^{7}$, Mohammad Hossein Khosravi ${ }^{7,8}$ and

Mohammad Hosein Amirzade-Iranaq 7,8,9,10*

*Address all correspondence to: h.amirzade@gmail.com

1 Department of Oral \& Maxillofacial Surgery, Faculty of Dentistry, Birjand University of Medical Science, Birjand, Iran

2 Vice Presidential Organization of Technology of the Islamic Republic of Iran, Iran

3 Stem Cell \& Regenerative Medicine Network, Shahid Beheshti University of Medical Sciences, Tehran, Iran

4 Cranio Maxillofacial Research Center, Tehran Dental Branch, Islamic Azad University, Tehran, Iran

5 Oral and Maxillofacial Surgery, Jundishapur University of Medical Sciences, Ahvaz, Iran 6 Private Practice, Tehran, Iran

7 Student Research Committee (SRC), Baqiyatallah University of Medical Sciences, Tehran, Iran

8 International Otorhinolaryngology Research Association (IORA), Universal Scientific Education and Research Network (USERN), Tehran, Iran

9 Student Research Committee, Shahid Sadoughi University of Medical Sciences, Yazd, Iran

10 Universal Network of Interdisciplinary Research in Oral and Maxillofacial Surgery (UNIROMS), Universal Scientific Education and Research Network (USERN), Tehran, Iran

\section{References}

[1] Lanza R, Langer R, Vacanti JP. Principles of Tissue Engineering. Academic Press; Elsevier Academic Press: MA, USA. 2011

[2] Fisher MB, Mauck RL. Tissue engineering and regenerative medicine: Recent innovations and the transition to translation. Tissue Engineering Part B: Reviews. 2013;19(1):1-13

[3] Salih V. Biodegradable scaffolds for tissue engineering. Cellular response to biomaterials. Boca Raton: CRC Press; 2008. p. 185-211

[4] Mihaylova Z, Mitev V, Stanimirov P, Isaeva A, Gateva N, Ishkitiev N. Use of platelet concentrates in oral and maxillofacial surgery: An overview. Acta Odontologica Scandinavica. 2017;75(1):1-11 
[5] Y-f L, Zhu F-d, Dong X-t, Peng W. Digital design of scaffold for mandibular defect repair based on tissue engineering. Journal of Zhejiang University Science B. 2011;12(9):769

[6] Seo S, Na K. Mesenchymal stem cell-based tissue engineering for chondrogenesis. BioMed Research International. 2011;2011:163-170

[7] Betz VM, Betz OB, Harris MB, Vrahas MS, Evans CH. Bone tissue engineering and repair by gene therapy. Frontiers in Bioscience. 2008;13(13):833-841

[8] Depprich R, Handschel J, Wiesmann H-P, Jäsche-Meyer J, Meyer U. Use of bioreactors in maxillofacial tissue engineering. British Journal of Oral and Maxillofacial Surgery. 2008;46(5):349-354

[9] Deb S, Mandegaran R, Di Silvio L. A porous scaffold for bone tissue engineering/45S5 bioglass ${ }^{\circledR}$ derived porous scaffolds for co-culturing osteoblasts and endothelial cells. Journal of Materials Science: Materials in Medicine. 2010;21(3):893-905

[10] Misch CE. Dental Implant Prosthetics-E-Book. Elsevier Health Sciences; 2014

[11] Aziz SR, Najjar T. Management of the edentulous/atrophic mandibular fracture. Atlas of the Oral and Maxillofacial Surgery Clinics. 2009;17(1):75-79

[12] Madsen MJ, Haug RH, Christensen BS, Aldridge E. Management of atrophic mandible fractures. Oral and Maxillofacial Surgery Clinics of North America. 2009;21(2):175-183

[13] Cawood J, Howell R. A classification of the edentulous jaws. International Journal of Oral and Maxillofacial Surgery. 1988;17(4):232-236

[14] Marx RE, Shellenberger T, Wimsatt J, Correa P. Severely resorbed mandible: Predictable reconstruction with soft tissue matrix expansion (tent pole) grafts. Journal of Oral and Maxillofacial Surgery. 2002;60(8):878-888

[15] Patel N, Kim B, Zaid W, Spagnoli D. Tissue engineering for vertical ridge reconstruction. Oral and Maxillofacial Surgery Clinics. 2017;29(1):27-49

[16] Giannobile W. Periodontal tissue regeneration by polypeptide growth factors and gene transfer. Tissue Engineering: Applications in Maxillofacial Surgery and Periodontics. 1999;1:231-243

[17] Guze KA, Arguello E, Kim D, Nevins M, Karimbux NY. Growth factor-mediated vertical mandibular ridge augmentation: A case report. International Journal of Periodontics \& Restorative Dentistry. 2013;33(5):611-617

[18] Simion M, Rocchietta I, Kim D, Nevins M, Fiorellini J. Vertical ridge augmentation by means of deproteinized bovine bone block and recombinant human platelet-derived growth factor-BB: A histologic study in a dog model. International Journal of Periodontics \& Restorative Dentistry. 2006;26(5):415-423

[19] Stephan EB, Renjen R, Lynch SE, Dziak R. Platelet-derived growth factor enhancement of a mineral-collagen bone substitute. Journal of Periodontology. 2000;71(12):1887-1892 
[20] Warnke P, Springer I, Wiltfang J, Acil Y, Eufinger H, Wehmöller M, et al. Growth and transplantation of a custom vascularised bone graft in a man. The Lancet. 2004;364(9436): $766-770$

[21] Meijer GJ, de Bruijn JD, Koole R, van Blitterswijk CA. Cell-based bone tissue engineering. PLoS Medicine. 2007;4(2):e9

[22] Patel N, Kim B, Zaid W, Spagnoli D. Tissue engineering for vertical ridge reconstruction. Oral and Maxillofacial Surgery Clinics of North America. 2017;29(1):27-49

[23] Melek LN. Tissue engineering in oral and maxillofacial reconstruction. Tanta Dental Journal. 2015;12(3):211-223

[24] Park J-B. Use of cell-based approaches in maxillary sinus augmentation procedures. Journal of Craniofacial Surgery. 2010;21(2):557-560

[25] Browaeys H, Bouvry P, De Bruyn H. A literature review on biomaterials in sinus augmentation procedures. Clinical Implant Dentistry and Related Research. 2007;9(3):166-177

[26] Tatum H Jr. Maxillary and sinus implant reconstructions. Dental Clinics of North America. 1986;30(2):207-229

[27] Boyne PJ. Grafting of the maxillary sinus floor with autogenous marrow and bone. Journal of Oral Surgery. 1980;38:613-616

[28] Summers RB. A new concept in maxillary implant surgery: The osteotome technique. Compendium (Newtown, Pa). 1994;15(2):152, 4-6, 8 passim; quiz 62

[29] Davarpanah M, Martinez H, Tecucianu J-F, Hage G, Lazzara R. The modified osteotome technique. International Journal of Periodontics \& Restorative Dentistry. 2001;21(6): 599-607

[30] Hallman M, Sennerby L, Lundgren S. A clinical and histologic evaluation of implant integration in the posterior maxilla after sinus floor augmentation with autogenous bone, bovine hydroxyapatite, or a 20:80 mixture. International Journal of Oral and Maxillofacial Implants. 2002;17(5):635-643

[31] Cammack GV, Nevins M, Clem DR, Hatch JP, Mellonig JT. Histologic evaluation of mineralized and demineralized freeze-dried bone allograft for ridge and sinus augmentations. The International Journal of Periodontics \& Restorative Dentistry. 2005;25(3):231-237

[32] Froum SJ, Wallace SS, Elian N, Cho SC, Tarnow DP. Comparison of mineralized cancellous bone allograft (Puros) and anorganic bovine bone matrix (Bio-Oss) for sinus augmentation: Histomorphometry at 26 to 32 weeks after grafting. International Journal of Periodontics \& Restorative Dentistry. 2006;26(6):543-551

[33] Pettinicchio M, Traini T, Murmura G, Caputi S, Degidi M, Mangano C, et al. Histologic and histomorphometric results of three bone graft substitutes after sinus augmentation in humans. Clinical Oral Investigations. 2012;16(1):45-53 
[34] Mangano C, Scarano A, Perrotti V, Iezzi G, Piattelli A. Maxillary sinus augmentation with a porous synthetic hydroxyapatite and bovine-derived hydroxyapatite: A comparative clinical and histologic study. International Journal of Oral \& Maxillofacial Implants. 2007;22(6):980-986

[35] Scarano A, Degidi M, Iezzi G, Pecora G, Piattelli M, Orsini G, et al. Maxillary sinus augmentation with different biomaterials: A comparative histologic and histomorphometric study in man. Implant Dentistry. 2006;15(2):197-207

[36] Schimming R, Schmelzeisen R. Tissue-engineered bone for maxillary sinus augmentation. Journal of Oral and Maxillofacial Surgery. 2004;62(6):724-729

[37] Schmelzeisen R, Schimming R, Sittinger M. Making bone: Implant insertion into tissueengineered bone for maxillary sinus floor augmentation - A preliminary report. Journal of Cranio-Maxillofacial Surgery. 2003;31(1):34-39

[38] Parveen S, Krishnakumar K, Sahoo S. New era in health care: Tissue engineering. Journal of Stem Cells \& Regenerative Medicine. 2006;1(1):8

[39] Jakobsen C, Sørensen J, Kassem M, Thygesen T. Mesenchymal stem cells in oral reconstructive surgery: A systematic review of the literature. Journal of Oral Rehabilitation. 2013;40(9):693-706

[40] Neiva RF, Tsao Y-P, Eber R, Shotwell J, Billy E, Wang H-L. Effects of a putty-form hydroxyapatite matrix combined with the synthetic cell-binding peptide P-15 on alveolar ridge preservation. Journal of Periodontology. 2008;79(2):291-299

[41] Gonshor A, McAllister BS, Wallace SS, Prasad H. Histologic and histomorphometric evaluation of an allograft stem cell-based matrix sinus augmentation procedure. International Journal of Oral \& Maxillofacial Implants. 2011;26(1):123-131

[42] Hermund NU, Stavropoulos A, Donatsky O, Nielsen H, Clausen C, Reibel J, et al. Reimplantation of cultivated human bone cells from the posterior maxilla for sinus floor augmentation. Histological results from a randomized controlled clinical trial. Clinical Oral Implants Research. 2012;23(9):1031-1037

[43] McAllister BS, Haghighat K, Gonshor A. Histologic evaluation of a stem cell-based sinus-augmentation procedure. Journal of Periodontology. 2009;80(4):679-686

[44] Kramer IR, Pindborg JJ, Shear M. Histological Typing of Odontogenic Tumours. Springer Science \& Business Media. Springer-Varlag: Berlin Heidelberg; 1992

[45] Mohammad Hosein Amirzade-Iranaq SMRM, Seied Omid Keyhan. Effectiveness of alloplastic materials in rhinoplasty surgery: A systematic review and meta-analysis. 15th International Congress of Iranian Society of Oral and Maxillofacial Surgeans (OMFS); Tehran, Iran. Tehran, Iran: Iranian Society of Oral and Maxillofacial Surgeans; 2017

[46] Kim YS, Park DY, Cho YH, Chang JW, Choi JW, Park JK, et al. Cultured chondrocyte and porcine cartilage-derived substance (PCS) construct as a possible dorsal augmentation 
material in rhinoplasty: A preliminary animal study. Journal of Plastic Reconstructive and Aesthetic Surgery. 2015;68(5):659-666

[47] Nerem R. Tissue engineering in the USA. Medical and Biological Engineering and Computing. 1992;30(4):CE8-CE12

[48] Rheinwatd JG, Green H. Seria cultivation of strains of human epidermal keratinocytes: The formation keratinizing colonies from single cell is. Cell. 1975;6(3):331-343

[49] Green H, Kehinde O, Thomas J. Growth of cultured human epidermal cells into multiple epithelia suitable for grafting. Proceedings of the National Academy of Sciences. 1979;76(11):5665-5668

[50] Yannas I, Burke J, Huang C, Gordon P. Correlation of in vivo collagen degradation rate with in vitro measurements. Journal of Biomedical Materials Research. 1975;9(6):623-628

[51] Yannas I, Burke JF. Design of an artificial skin. I. Basic design principles. Journal of Biomedical Materials Research. 1980;14(1):65-81

[52] O'Connor N, Mulliken J, Banks-Schlegel S, Kehinde O, Green H. Grafting of burns with cultured epithelium prepared from autologous epidermal cells. The Lancet. 1981;317(8211):75-78

[53] Green H. The birth of therapy with cultured cells. BioEssays. 2008;30(9):897-903

[54] Gallico GG III, O'Connor NE, Compton CC, Kehinde O, Green H. Permanent coverage of large burn wounds with autologous cultured human epithelium. New England Journal of Medicine. 1984;311(7):448-451

[55] Burke JF, Yannas IV, Quinby WC Jr, Bondoc CC, Jung WK. Successful use of a physiologically acceptable artificial skin in the treatment of extensive burn injury. Annals of Surgery. 1981;194(4):413

[56] Heimbach D, Luterman A, Burke J, Cram A, Herndon D, Hunt J, et al. Artificial dermis for major burns. A multi-center randomized clinical trial. Annals of Surgery. 1988;208(3):313

[57] Heimbach DM, Warden GD, Luterman A, Jordan MH, Ozobia N, Ryan CM, et al. Multicenter postapproval clinical trial of Integra ${ }^{\circledR}$ dermal regeneration template for burn treatment. Journal of Burn Care \& Research. 2003;24(1):42-48

[58] Heitland A, Piatkowski A, Noah E, Pallua N. Update on the use of collagen/glycosaminoglycate skin substitute-Six years of experiences with artificial skin in 15 German burn centers. Burns. 2004;30(5):471-475

[59] Shevchenko RV, James SL, James SE. A review of tissue-engineered skin bioconstructs available for skin reconstruction. Journal of the Royal Society Interface. 2009;7(43):229-258

[60] Chua AWC, Khoo YC, Tan BK, Tan KC, Foo CL, Chong SJ. Skin tissue engineering advances in severe burns: Review and therapeutic applications. Burns \& Trauma. 2016;4(1):3 
[61] MacNeil S. Progress and opportunities for tissue-engineered skin. Nature. 2007;445(7130): 874-880

[62] Conconi MT, Coppi PD, Liddo RD, Vigolo S, Zanon GF, Parnigotto PP, et al. Tracheal matrices, obtained by a detergent-enzymatic method, support in vitro the adhesion of chondrocytes and tracheal epithelial cells. Transplant International. 2005;18(6):727-734

[63] Van der Veen VC, van der Wal MB, van Leeuwen MC, Ulrich MM, Middelkoop E. Biological background of dermal substitutes. Burns. 2010;36(3):305-321

[64] Wainwright D. Use of an acellular allograft dermal matrix (AlloDerm) in the management of full-thickness burns. Burns. 1995;21(4):243-248

[65] Yu P, Qi Z. Prospective randomized comparison of scar appearances between Cograft of Acellular dermal matrix with autologous split-thickness skin and autologous splitthickness skin graft alone for full-thickness skin defects of the extremities. Plastic and Reconstructive Surgery. 2016;137(5):906e

[66] Kim RY, Bae SS, Feinberg SE. Soft tissue engineering. Oral and Maxillofacial Surgery Clinics of North America. 2017;29(1):89-104

[67] Izumi K, Neiva RF, Feinberg SE. Intraoral grafting of tissue-engineered human oral mucosa. The International Journal Of Oral \& Maxillofacial Implants. 2013;28(5):e295

[68] Crisciani S. Efficacia Clinica Degli Innesti di Collagene Xenogeno Nella Terapia Chirurgica delle Recessioni Gengivali multiple: Clinical Trial Randomizzato. Graduate thesis LC5. Universita Di Pisa; 2012

[69] Nevins M. Attached gingiva-mucogingival therapy and restorative dentistry. The International Journal of Periodontics \& Restorative Dentistry. 1985;6(4):9-27

[70] Wennström JL, Zucchelli G. Increased gingival dimensions. A significant factor for successful outcome of root coverage procedures? Journal of Clinical Periodontology. 1996;23(8):770-777

[71] McGuire MK, Scheyer ET, Nunn ME, Lavin PT. A pilot study to evaluate a tissueengineered bilayered cell therapy as an alternative to tissue from the palate. Journal of Periodontology. 2008;79(10):1847-1856

[72] Nevins ML. Tissue-engineered bilayered cell therapy for the treatment of oral mucosal defects: A case series. International Journal of Periodontics \& Restorative Dentistry. 2010;30(1):31-39

[73] Prato GPP, Rotundo R, Mognoni C, Soranzo C. Tissue engineering technology for gingival augmentation procedures: A case report. International Journal of Periodontics \& Restorative Dentistry. 2000;20(6):552-559

[74] Chen H-CJ, Chen H-L, Lai J-Y, Chen C-C, Tsai Y-J, Kuo M-T, et al. Persistence of transplanted oral mucosal epithelial cells in human cornea. Investigative Ophthalmology \& Visual Science. 2009;50(10):4660-4668 
[75] Izumi K, Inoki K, Fujimori Y, Marcelo C, Feinberg S. Pharmacological retention of oral mucosa progenitor/stem cells. Journal of Dental Research. 2009;88(12):1113-1118

[76] Pomahač B, Svensjö T, Yao F, Brown H, Eriksson E. Tissue engineering of skin. Critical Reviews in Oral Biology \& Medicine. 1998;9(3):333-344

[77] C-y T, Ueda M, K-i H, Horie K, Hibino Y, Sugimura Y, et al. Clinical results of cultured epithelial cell grafting in the oral and maxillofacial region. Journal of CranioMaxillofacial Surgery. 1997;25(1):4-8

[78] Yoshizawa M, Feinberg SE, Marcelo CL, Elner VM. Ex vivo produced human conjunctiva and oral mucosa equivalents grown in a serum-free culture system. Journal of Oral and Maxillofacial Surgery. 2004;62(8):980-988

[79] Aryaei A, Vapniarsky N, JC H, Athanasiou KA. Recent tissue engineering advances for the treatment of temporomandibular joint disorders. Current Osteoporosis Reports. 2016;14(6):269-279

[80] $\mathrm{Hu}$ JC, Athanasiou KA. A self-assembling process in articular cartilage tissue engineering. Tissue Engineering. 2006;12(4):969-979

[81] Vacanti JP, Morse MA, Saltzman WM, Domb AJ, Perez-Atayde A, Langer R. Selective cell transplantation using bioabsorbable artificial polymers as matrices. Journal of Pediatric Surgery. 1988;23(1):3-9

[82] Murphy MK, MacBarb RF, Wong ME, Athanasiou KA. Temporomandibular joint disorders: A review of etiology, clinical management, and tissue engineering strategies. The International Journal of Oral \& Maxillofacial Implants. 2013;28(6):e393

[83] Boyne PJ, Lilly LC, Marx RE, Moy PK, Nevins M, Spagnoli DB, et al. De novo bone induction by recombinant human bone morphogenetic protein-2 (rhBMP-2) in maxillary sinus floor augmentation. Journal of Oral and Maxillofacial Surgery. 2005;63(12):1693-1707

[84] Woo EJ. Adverse events reported after the use of recombinant human bone morphogenetic protein 2. Journal of Oral and Maxillofacial Surgery. 2012;70(4):765-767

[85] Zhang Z. Bone regeneration by stem cell and tissue engineering in oral and maxillofacial region. Frontiers of Medicine. 2011;5(4):401-413

[86] Ripamonti U, Tsiridis E, Ferretti C, Kerawala CJ, Mantalaris A, Heliotis M, Ripamonti U, Tsiridis E, Ferretti C, Kerawala CJ, Mantalaris A, Heliotis M. Perspectives in regenerative medicine and tissue engineering of bone. British Journal of Oral and Maxillofacial Surgery. 2011;49(7):507-509 
